\title{
Kentsel İnovasyonun Kentleşme Üzerine Mekânsal Etkisi
}

\author{
M. Kenan Terzioğlu1 \\ ORCID: 0000-0002-6053-830X \\ Senem Demirkıran ${ }^{3}$ \\ ORCID: 0000-0001-9835-4963
}

\author{
Mehmet Ali Yücel ${ }^{2}$ \\ ORCID: 0000-0002-5474-3307 \\ Doğaç Acaroğlu 4 \\ ORCID: 0000-0002-0055-1449
}

Öz

Gelişen teknoloji ve küreselleşmeyle değişen toplum yapısına uyum sağlayan kentler inovasyon süreci içinde etkileşim sağlanan, yeni fikirlerin ortaya çıktığı ve bilginin yayıldığı açık sistemler olarak ortaya çıkmaktadır. Yapay zekanın, robotların ve bilişim sistemlerinin günlük hayatımızda yer aldığı, her gün bilinmeyenle ilgili yeni bilgilere eriştiğimiz çă̆da, dünya nüfusunun yarısı kentlerde yaşamakta ve kent sakinleri dünyanın doğal kaynaklarının dörtte üçünden fazlasını tüketmektedir. Hızlı kentleşme ve nüfus artışı sorunları beraberinde getirmekte ve kentlerin yaşanabilir olma özelliklerini kaybetmelerine neden olmaktadır. Hızl kentleşmenin bir krize dönüşmesini engellemek için kentleri yenilikçi bir yaklaşımla donatmak ve yönetmek çağın gerekliliğidir. Bu gerekliliğin sonucunda, kentsel inovasyon hızlı kentleşmenin ortaya çıkardı ̆̆ karışıklı̆̆ı ve sorunları çözmenin bir yolu olarak ortaya çıkmaktadır. Makale kapsamında, 2018 yilı baz alınarak elde edilen kentsel inovasyon göstergelerinden araştırma-geliştirme faaliyet göstergelerinin ve çevresel faaliyet göstergelerinin kentleşmeyi olumsuz yönde etkilerken; sağı̆ğa yapılan yatırımları gösteren faaliyetlerin, altyapı faaliyet göstergelerinin ve bireysel yatırım-tasarruf göstergelerinin kentleşme üzerinde olumlu yönde etkisi olduğu belirlenmiştir.

Anahtar Kelimeler: Mekânsal ekonometri, kentleşme, kentsel inovasyon

\footnotetext{
${ }^{1}$ Doç. Dr., Trakya Üniversitesi, E-mail: kenanterzioglu@trakya.edu.tr

${ }^{2}$ Trakya Üniversitesi, E-mail: maliiyucell@gmail.com

${ }^{3}$ Öğr. Gör., Trakya Üniversitesi, E-mail: senemdmk@gmail.com

${ }^{4}$ Trakya Üniversitesi, E-mail: dogacacaroglu@gmail.com

idealkent @ Kent Araştırmaları Dergisi (Journal of Urban Studies) 


\title{
Spatial Effect of Urban-Innovation on Urbanization
}

\author{
M. Kenan Terzioğlu ${ }^{5}$ \\ ORCID: 0000-0002-6053-830X
}

Senem Demirkıran
ORCID: 0000-0001-9835-4963

\author{
Mehmet Ali Yücel ${ }^{6}$ \\ ORCID: 0000-0002-5474-3307 \\ Doğaç Acaroğlu ${ }^{8}$ \\ ORCID: 0000-0002-0055-1449
}

\begin{abstract}
Cities, adapting to changing society structure with developing technology and globalization, are open systems where interactions within the innovation process, new ideas emerge and information spreads. In the age where artificial intelligence, robots and information systems are in our daily lives and we have access to new information about the unknown, half of the world's population lives in cities and urban residents consume more than three quarters of the world's natural resources. Rapid urbanization and population growth bring along problems and cause cities to lose their livability. To prevent rapid urbanization from turning into a crisis, it is necessary to equip and manage cities with an innovative approach. As a result of this requirement, urban innovation emerges as a way to solve the confusion and problems caused by rapid urbanization. In the context of the article, within the urban innovation indicators obtained on the basis of 2018, it was determined that while the research-development activity indicators and environmental activity indicators negatively affect urbanization, the health investment, infrastructure activity and individual investment-saving indicators affect urbanization positively.
\end{abstract}

Keywords: Spatial econometrics, urbanization, urban innovation

\footnotetext{
${ }^{5}$ Assoc. Prof.., Trakya University, E-mail: kenanterzioglu@trakya.edu.tr

${ }^{6}$ Trakya University, E-mail: maliiyucell@gmail.com

${ }^{7}$ Lecturer See., Trakya University, E-mail: senemdmk@gmail.com

${ }_{8}^{8}$ Trakya University, E-mail: dogacacaroglu@gmail.com

idealkent @ Kent Araştırmaları Dergisi (Journal of Urban Studies) 


\section{Giriş}

Kentlerdeki sosyal, ekonomik, çevresel ve yönetişim zorluklarının aşılmasının yollarının ve araçlarının bulunmasını merkezinde barındıran kentsel inovasyon, yerel yönetimlerin vatandaşlarının yaşam kalitesinin iyileştirilmesine ivme kazandırmaktadır (Nam ve Pardo, 2011, s. 185). Fursatları ve riskleri içinde barındıran, yenilik olarak ifade edilen inovasyon, kentlerin akıllı politikalar tanımlaması için gereklidir (Mitchell, 2007, s. 3-4). İnovasyon olarak nitelendirilen akıllı kent, riskleri bilinmeyen karmaşık nesne haline gelebilmektedir. Teknik olmayan yönetim ve politika kentsel inovasyonun başarısını etkilemektedir. Yüksek risklerin yönetimindeki başarısızlık, teknoloji odaklı kamu sektörü projelerinde başarısızlığa yol açtığından inovasyon risklerinin kamu otoriteleri tarafından iyi yönetilmesi gerekmektedir (Gutzmer, 2016, s. 56-59). Endüstri 5.0 çerçevesinde kentsel inovasyon; teknoloji, yönetim ve politika kapsamından oluşmaktadır. Teknoloji, hizmetleri geliştirmek ve hizmetlerde kullanılan araçların daha faydalı olabileceği koşullar yaratmak için teknoloji kullanımını ifade etmektedir. Yönetim, teknolojik araçların etkin kullanımın sağlarken; uygulanacak politika kurumsal ve teknik olmayan kentsel sorunları ele alan ve kentsel inovasyon için uygun koşulları yaratan mekanizmalar olarak işlemektedir (Capello, 2001, s. 181).

Kent için oluşturulan politikalar kentlerin bölgesel/ulusal/uluslararası ilişkilerinin şekillenmesinde ve değiştirilmesinde önemli role sahip olduğundan, uygulanan (uygulanması planlanan) politikalar ve koordinasyonlar kentsel inovasyon için önemlidir. Bununla birlikte, teknolojik yenilik kentsel inovasyonda daha belirgin ve anlaşlırken; hükümet politikalarının kentin ihtiyaçlarına göre yeniden düzenlenmesiyle oluşturulan politikalardaki yenilikler belirsizlik içermektedir. Bu kapsamda, kamu otoriteleri kentsel inovasyonda üç politik yenilik yöntemi izlemektedirler: Politika entegrasyonu, kentin daha iyi pazarlanması için markalaşma ve talep odaklı girişimdir. Sektörel entegrasyon, politika alanları ile sektörlerin koordinasyonu; yatay entegrasyon, kentsel alandaki aktörler arasındaki politika uyumunu ve dikey entegrasyon ise devletin farklı kademeleri arasındaki koordinasyonu ifade etmektedir.

Günümüzde ülkeler yerine marka kentler ön plana çıtığından, rekabet ülkelerin yanı sıra kentler, insanlar, fikirler, teknolojiler ve sermayeler arasında gerçekleşmekte ve kent inovasyonunda kentin pazarlanması önemli olmaktadır. Bu çerçevede, politika boyutundan incelendiğinde inovasyon marka stratejisi gerektirmektedir. Kentsel inovasyonda markalaşma mıknatıs 
görevi görerek kentlere yeni kaynaklar ve yatırımlar çekmektedir. Kentin sürdürülebilir büyümesini teşvik etmek ve kenti diğer kentlerden farklı kılmak ancak sonuca odaklanan ve desteklenen bir markalaşma stratejisi ile gerçekleştirilebilmektedir. Kentsel inovasyonda kullanılan diğer politik yenilik ise talep odaklı girişimdir. Başarılı kentsel inovasyon uygulamalarında politikalar arza değil talebe dayalı olmaktadır. Talep ve arz arasındaki fark sadece ekonomik faaliyetleri değil, aynı zamanda, kentsel inovasyon girişimi için kamu otoritelerinin gücü ile sivil toplum kuruluşlarının girişimde yer alması arasındaki zıtlığı da açıklamaktadır. İnovasyonda talep odaklı politikalar daha iyi yönetişime yol açmakta ve başarılı inovasyon kilit paydaşların katılımıyla gerçekleşmektedir. Kentsel inovasyon ile kentlerde farklı sektörler ve farklı yetki alanları arasında iş birliği gerçekleşmektedir. Talep odaklı girişim ayrıca vatandaş odaklı ă̆ yönetişimini teşvik ederek vatandaş katılımının sağlanmasına, kentli olma duygusunun geliştirilmesine ve vatandaş-kamu otoriteleri arasındaki ilişkilerin şekillendirilmesine katkı sağlamaktadır (Dente vd., 2012, s. 41-52). Kentlerin inovasyon stratejisi tasarlama şekli farklı olduğundan, risklerin ve firsatların tespit edilerek stratejilerin belirlenmesi gerekmektedir. Kentlerin farklı özelliklere sahip olmalarının dışında çok daha önemli olan bir diğer sorun ise kent içinde ki dengesizlikten kaynaklanan kentsel yoksulluktur. Yetenekler ve yaratıcılık kenti oluşturan tüm unsurları bir araya getirerek inovasyonu ortaya çıkardığından ve inovasyon ise bir bütün olarak insanları, finans bölgelerini, sanayi bölgelerini ve kültürel bölgeleri kapsadığından, kentsel yoksulluk uygulanacak olan inovasyonu doğrudan etkilemektedir.

Makale kapsamında, 2018 yılı temel alınarak, kentsel inovasyon göstergeleri olarak ele alınan çevresel faaliyet göstergelerinin, altyapı göstergelerinin, AR-GE faaliyet göstergelerinin, sağlık sektörü yatırım göstergelerinin ve bireysel yatırım-tasarruf göstergelerinin kentleşme üzerindeki etkilerinin ortaya çıkarılmasının yanı sıra kentleşmenin mekânsal bir dağılıma sahip olup olmadığının araştırılmasıyla literatüre katkı yapılması amaçlanmaktadır.

Ek olarak, kentsel inovasyon göstergesi olarak ele alınan değişkenler Türkiye'de sürdürülebilir ekonomik yapının mı yoksa sadece büyüme odaklı bir yapının mı hâkim olduğu hakkında bilgi sağlayabilmektedir. Çalışma kapsamında, beşerî sermaye, çevre ve alt yapıyı ifade eden göstergeler ele alınarak kentleşmedeki artışın kentsel inovasyondan mı yoksa kırsal kesimden kaçış kapsamında içinde eko-inovasyon ve eko-verimliliği barındırmayan sanayileşmeye dayanan sadece büyüme odaklı bir ekonomi kapsamında ortaya 
çıkan kentleşme olgusundan mı kaynaklandığının ortaya çıkartılması planlanmaktadır. Bu çerçevede, iller bazında patent ve faydalı model sayısındaki artışın, ortalama atık miktarlarının ve orman alanının kentleşme üzerinde negatif yönde etkisinin bulunması nedeniyle sürdürülebilir büyüme ve verimlilik kapsamında kentsel inovasyonun tam olarak sağlanamadığı sadece büyüme odaklı bir sürecin var olduğu ve bu nedenle, kentleşmenin sadece kırsal kesimdeki kentleşme türü olan kente göç olarak değerlendirilebileceği sonucuna ulaşılmaktadır.

\section{Kavramsal Çerçeve}

İnovasyon, üreticinin uzun vadede rekabet gücünü ve performansını arttırarak ekonomik gelişme, uluslararası ticaret ve bölgesel refah getiren teknolojik ilerleme ve gelişmeyi birbirine bağlamaktadır. Ekonomik faaliyetlerin ve teknoloji inovasyonunun meydana geldiği kentlerdeki verimlilik avantajları kentin inovasyon kapasitesinden kaynaklanmaktadır (BM, 2013, s. 7-8). İnovasyon kapasitesi hem üreticinin rekabet gücünü hem de verimliliği artırmada önemli bir faktördür. Kentsel verimliliğgi arttırmak için endüstri alanları ve sanayi bölgelerinin oluşturulması sonucu ortaya çıkan teknolojik büyüme ve iş olanakları ise verimlilik ve inovasyon ilişkisini ortaya çıkarmaktadır. Endüstri alanlarında yüksek teknolojinin kullanılmasıyla ve ürün üretim maliyetinin düşmesiyle üreticiler yüksek verimlilik elde etmekte ve yeni yaratılan iş firsatları ile işsizlik azaltılmaktadır. Kentlerdeki yenilikçi ortamlar üretim performansını arttırarak kentlere rekabet gücü de kazandırmaktadır. Bu ortamlar endüstri bölgelerini, kooperatifleri, üreticilerin araştırma geliştirme (AR-GE) faaliyetleri ile inovasyon seviyelerini ve diğer faktörleri bir araya getirmektedir. AR-GE fonlarının girişi inovasyonun bir çıtı olacağını göstermektedir. İnovasyon faaliyetlerinin merkezi olan AR-GE'ye yapılan yatırımlar artan verimlilik ile birlikte artmakta ve kentsel verimlilik sonucu ortaya çıkan bu yatırımlar kentin yaşam kalitesini yükseltmektedir (Fischer ve Wang, 2011, s. 56). Yoksul bireylerin büyük kısmının kırsal alanlarda yaşadığ 1 bilinmesine rağmen daha iyi ücretlerle, daha iyi imkanlarla ve işsizlik nedeniyle farklı sektörlerde çalışmak için kırdan kentlere göç yaşanmakta ve kentler kalabalıklaşmaktadır. Kentlerdeki yoksul sayısının nüfus artışından daha hızlı artması ve daha iyi bir iş ya da farklı nedenlerle göç edenlerin gecekondu mahallelerinin büyümesine neden olması yoksulluk ile birlikte kentleşme oranında artış yaratmaktadır (Oosterlynck vd., 2013, s.16). Ekonomik İş bir- 
liği ve Kalkınma Örgütü (OECD) 2011-2020 dönemi kentsel politika incelemelerinde, yoksulluk ile ilgili kentleşmenin kentsel nüfus üzerinde etkisinin olduğu ve yeni kent sakinlerinin eski kent sakinlerine göre daha yoksul olma eğiliminde oldukları belirtilmektedir (OECD, 2020, s. 1-12). Sürdürülebilir kentsel politikalar ile kentsel yoksulluk azaltılabilmektedir. Bu çerçevede, İngiltere' de çekirdek şehirlerde (Belfast, Birmingham, Bristol, Cardiff, Glasgow, Leeds, Liverpool, Manchester, Newcastle, Nottingham ve Sheffield) verimliliği artırma kentsel politikası kapsamında, sürdürülebilir kentsel politikalarla verimlilik seviyelerinde artmayla birlikte kentsel yoksullukta azalma hedeflenmektedir (OECD, 2020, s. 1-20).

Kentsel inovasyon, kentsel nüfusun ihtiyaçlarını daha verimli, etkili ve sürdürülebilir bir şekilde karşılayan yeni yöntem, iş modeli, politika, kurumsal tasarım veya düzenlemeyi ifade etmektedir. Kentsel inovasyonda, kente göç eden nüfusun kent içi projelerde istihdam edilmesiyle gelir seviyesinin arttırılması kentsel yoksulluğu azaltmada önemli faktörlerdendir (Demiral vd., 2007, s. 4). Gelişmekte olan ülkeler başta olmak üzere, huzlı kentleşmede yaşanan temel zorluklar arasında kentsel yayılım, altyapı eksikliği, kaynakların bilinçsiz tüketilmesi, çevresel bozulma ve doğal afet riskleri yer almaktadır (Ritchie ve Roser, 2019). Sürdürülebilir kentsel politikalarda, özellikle kentsel inovasyon stratejilerinde, kent yönetimlerinin kent sakinlerinin refah seviyesini arttıracak politikalara yönlenmeleri sağlanmaktadır (Berdegué ve Escobar, 2002, s. 1). Bu kapsamda, Birleşmiş Milletler Ekonomik ve Sosyal Konsey'in Bilim ve Teknoloji Geliştirme Komisyonu tarafından yapılan sürdürülebilir kentler için bilim, teknoloji ve inovasyon araştırmasında, sürdürülebilir büyüme ve gelişme için önerilen kentsel inovasyon seçenekleri arasında yenilikçi kentsel yönetişim ve mekânsal planlama-tasarım yer almaktadir (BM, 2013).

Kentsel inovasyon, hızlı teknoloji dönüşümüyle kullanımı artan robotlar, beyin-makine ara yüzü ve yapay zekada ki ilerlemeler sayesinde önemli hale gelmektedir. Teknolojinin toplumlar tarafından bir tehdit olarak değil, bir yardımcı olarak algılanması gerekliliği görüşü üzerine dayanan ve insan merkezli felsefeyi barındıran Endüstri 5.0 kavramı, bireylerin rahatlığı ve yararı için ileri Bilgi Teknolojileri (BT), Nesnelerin İnterneti (IoT), robotlar, yapay zekâ, arttırılmış gerçeklik gibi araçların insanların ortak yaşamında, endüstride, sağlık hizmetlerinde ve diğer alanlarda aktif olarak kullanıldığı bir toplumu ifade etmektedir (Skobelev ve Borovik, 2017, s. 306). Endüstri 5.0, siber alan ve fiziksel alanın (gerçek toplumun) yüksek seviyede entegre olduğu, süper akıllı toplum olarak tanımlanmaktadır. Endüstri 5.0, Endüstri 
4.0'in yarattığ yardımcı robotlar ve yapay zekalar olduğunu vurguladığından yasal düzenlemeler, iş akışları, görev tanımları vb. gibi değişiklikler yapay zekaların kullanımı ile ilgili düzenlemeler içermektedir. Değişim sürecinde olan dijital teknolojiler ve yapay zekâ tabanlı çözümler ile zirvede kalmak zorlaştı̆̆ından, makinelerin insanların işlerinde kullanılmaya başlamasıyla tüm sektörlerde insanlara gerek kalmayacağından kaynaklanan korku olgusuyla, gelişmiş ülkeler Endüstri 4.0'da ki gelişimlerini tamamlamadan Endüstri 5.0'a geçmek için girişimlerde bulunmaya başlamışlardır. Amacının sosyal sorunların teknolojik gelişimle çözülmesi ve robotların insanların hayatını kolaylaştırması olarak ifade edilen Endüstri 5.0, robotların insanların işlerini ellerinden aldığ 1 değil, insanlarla ortak çalıştı̆̆ bir dönemi ifade etmektedir (Nahavandi, 2019, s. 1). Tablo 1.'de yer alan Endüstri 5.0 vizyonlarının ilkinde robot ve insanlar mümkün olan her yerde/zamanda birlikte çalışmaktadır. İnsanlar yaratıcılık gerektiren görevlere odaklanırken diğer gerekli işlemleri robotlar yapmaktadır. İkinci vizyon ise biyolojik kaynakların endüstriyel amaçlarla akıllıca kullanılarak ekoloji, endüstri ve ekonomi arasında bir denge kurulmasına yardımcı olmaktadır (Demir vd., 2019, s. 689). Gelişmiş ülkeler bilgi toplumu çerçevesinde Endüstri 5.0'ın da etkisiyle insan odaklı ve çevreye duyarlı teknolojiler kullanarak kentsel gelişmeyi sağlamaktadır Tekeli (2019, s. 5).

Tablo 1. Endüstri 5.0 vizyonları

\begin{tabular}{lll}
\hline & Endüstri 5.0 (1.Vizyon) & Endüstri 5.0 (2.Vizyon) \\
\hline Slogan & İnsan-robot iş birliği & Biyo-ekonomi \\
\hline Motivasyon & Akıllı Toplum & Sürdürülebilirlik \\
\hline Güç Kaynağı & Elektrik gücü, & Elektrik gücü, \\
& Yenilenebilir güç kaynakları & Yenilenebilir güç kaynakları \\
\hline \multirow{2}{*}{ Aktif Teknolojisi } & İnsan-Robot iş birliği, & Sürdürülebilir Tarım, Üretim \\
& Yenilenebilir kaynaklar & Biyonik, Yenilenebilir kaynaklar \\
\hline Aktif & Akıllı Ortamlar, Örgütsel & Tarım, Biyoloji, Atık Önleme, \\
Araştırma Alanları & Araştırma, Süreç, Yenilik ve & Süreç İyileştirme ve yenilik, \\
& İyileştirme, İşidaresi & İşidaresi, Ekonomi \\
\hline
\end{tabular}

Kaynak: Demir vd.,2019:690

Kentsel inovasyon çerçevesinde Endüstri 5.0 ile birlikte teknoloji transferi inovasyon sürecini canlandırmakta ve güçlendirmektedir. Teknoloji transferi bir teknolojiyi bir taraftan diğerine aktarma ve benimsetme sürecidir. Bu süreç kentlerin sorunlarını çözüp kentleri rekabet edebilir konuma getirmek 
için uygulanan kentsel inovasyonda yeni ürünlerin yaratılma sürecini ve bilginin kullanılmasını ifade etmektedir. Teknoloji transferi, yeni ürünlerin eski ürünlere dönüştürülme süreci olduğundan kentsel inovasyonda kentin dönüştürülmesi için teknoloji transferi ve ihracatı önemli bir yer tutmaktadır. Teknoloji transferi ve bilginin edinilmesi anlamına gelen teknoloji ihracatı, kent içinde yenilik yaratma süreci olarak tanımlanabilmekte ve kentin diğer kentlerle rekabet edebilirliğini arttıran gösterge olmaktadır. Kentler teknoloji ve bilgiyi transfer ederek geliştirip ihraç etme yeterliliğine sahip olduklarında sürdürülebilir kalkınma gerçekleşmektedir (Krugman, 1979, s. 259). Maddi ve maddi olmayan bileşenleri kapsayan teknolojiye sahip olmak ve teknolojiyi kullanmak ülkelerin hızlandırılmış kalkınmalarında, özellikle sanayileşme çerçevesinde, hedef haline gelmektedir. Ülkeler ulusal kalkınma hedefi belirleyerek uygun sanayileşme stratejisi seçmektedirler. Teknolojiyi üretemeyen ülkeler teknolojik, sosyal ve ekonomik kalkınmalarını sağlamak için teknoloji transferi yapmaktadırlar. Diğer taraftan, teknoloji transferi ortaya çıkan olumsuz sosyo-ekonomik koşullar nedeniyle beklenen sonuçları vermemektir.

Alıcı bölge veya ülkenin alınan bilgiyi kullanmasını sağlayan yararlı fikir ve yenilik alışverişi olan teknoloji transferi; bilgi, beceri, organizasyon ve sermayenin üretim noktasından uygulama alanına hareketini ifade etmektedir. Teknoloji transferinde fiziksel varlıklarla birlikte bilgide transfer edilmezse teknoloji ithal eden ülke bu teknolojiyi kullanma konusunda verimlilik sağlayamamaktadır (Akubue, 2002, s. 16). Ulusal sinırlarla sinırlı olmayan ulusötesi kavram olan bilginin yayılması kentsel inovasyonun şekillenmesinde kilit rol oynamaktadır. Kentler arasındaki rekabet, yararlı bilginin artması ve uygulanması ile mümkün olan kentsel sürdürülebilir kalkınmayla sağlanmaktadır. Kentsel inovasyonla mevcut/yeni bilgiler firmalar, müşteriler ve kamu kurumları arasında etkileşim yaratıp paylaşıldığından ulusal sürdürülebilir kalkınma için başarılı bilgi yönetimi gerekmektedir (Kremic, 2003, s. 149). Kentin içindeki farklılıklardan ötürü bilgi kent içinde farklı boyutlarda yayıldığından kentsel inovasyonda teknoloji transferini başlı başına amaç veya sonuç olarak görmek yanlış olmaktadır. Kamu otoriteleri kentlerde yaşayan insanlar için kentleri dönüştürdüklerinden kentsel inovasyon sürecinde kullanılan teknoloji transfer yöntemlerine bireylerin motivasyonu da dahil edilmektedir (Simmie, 2003, s. 607).

İnovasyon ile kentsel kalkınmayı birbirine bağlamanın temel yolu AR-GE faaliyetleri, teknoloji üreten kurumlar ve finansmandır. İnsan, kültür ve toplum bilgisi dahil bilgi stokunu artırma ve yenilik için kullanma çalışmalarını 
içeren AR-GE faaliyetleri (teorik/uygulamalı araştırma ve deneysel geliştirme yöntemleri), teknoloji transferiyle elde edilen bilgileri de işlemektedir. Küresel inovasyon ağları ve dijital iş birliği ağları tarafından şekillendirilen kentsel inovasyon sistemlerinde uygun AR-GE politikalarının benimsenmesi gerekmektedir (Kominos ve Sefertzi, 2009, s. 1). AR-GE ile inovasyon ilişkisi incelendiğinde AR-GE'nin yenilik yapmak için daha fazla girdiye ihtiyaç duyarken inovasyon daha fazla bilgiye ihtiyaç duymaktadır. Bu nedenle, ulusal ve yerel (kentsel) olarak yoğunlaşan inovasyon politikaları için kamu desteği ve çeşitli çevresel koşulların mevcut olması gerekmektedir. AR-GE faaliyetleri hemen hemen tüm ülkelerde gerçekleştirilirken, inovasyon faaliyetleri gelişmiş ülkelerde daha yaygin olmakla birlikte gelişmekte olan ülkelerde kentsel inovasyon süreçleri işlerlik kazanmaya başlamaktadır. Endüstriyel ve teknolojik üretim faktörlerine yönelen kentlerin sürdürülebilir kalkınma ve rekabet edebilme gücü sağlaması ekonomik faaliyetlerindeki çeşitliliğe, üretken ekonomik aktörlerine, ürün çeşitliliğine, yüksek düzeyde iş birliklerine ve ücretlere bağlı olmaktadır. Rekabet edebilir kent olma düşüncesiyle, dijital çağda teknolojiye dönük araştırmaların artarak, endüstri alanlarının kentsel yaşam sürecine dahil edilmesi ve kentsel inovasyon gerçekleştirmek için AR-GE yatırımlarının artması patent başvurularında artışı ve bilginin yayılması/ölçülmesi çalışmalarını hızlanmaktadır. Patent olgusunun yanı sıra mevcut ürünü daha iyi konuma getiren eklentileri ve yenilemeleri ifade eden ve özellikle gelişmekte olan ve alınan teknolojinin, teknolojiyi ithal eden ülkelerde, geliştirilmesi ile ülke ekonomisine katkı sağlayan faydalı modeller de oluşturulmaktadır. Patentten farklı olarak faydalı model, icat/yeni bir buluş yapılması zorunluluğunu barındırmamakla birlikte endüstride fayda sağlayan ve yenilik özelliği olan teknik bilginin korunması için kullanılmaktadır. Hem patent hem faydalı model belgesi verilememekte, faydalı model olarak başlatılan araştırma patente dönüştürülebilmekte ve faydalı model tasarım olarak tescil edilebilmektedir. Gelişmekte olan ülkelerde, rekabet edebilme gücü faydalı model ile sağlandığından faydalı model ile ilgili yasal korumaya da ihtiyaç vardır. Gelişmiş ülkelerde ise, teknoloji üreten kuruluşlar buluşlarını patentle geniş kapsamda koruma altına aldıklarından faydalı model ile ilgili ayrıca herhangi bir yasal düzenlemeye ihtiyaç duymamaktadırlar. Faydalı modelin kentsel inovasyon için önemi faydalı modelin patente göre daha esnek olmasıdır. Kentsel inovasyon stratejisinde esneklik faktörünün politika uygulamadaki yeri düşünüldüğünde faydalı modelin önemi ortaya çıkmaktadır (Suthersanen, 2006, s. 1). 
Kamu otoriteleri tarafindan kalkınma odaklı kentsel inovasyon sürecinde karşılaşılan çevresel baskılar; ekonomik zorunluluk, düzenleyiciler, kamu baskısı, yoğun şehirlerarası rekabet, devletin yeniden yapılanması olarak beş başlık altında incelenmektedir (While vd., 2004, s. 552). Kentler sürdürülebilir kalkınma için çevreye dost mekânsal çözüm arayışları içinde yer almaktadırlar (Mol, 2009, s. 96). Sürdürülebilirlik için çevreci yaklaşımlarla birlikte çevreyle ilgili toplumsal bilinç düzeyinin artması, çevreye duyarlı teknolojilerin gelişmesi ve kullanımlarının artması gerektiğinden kamu otoritelerinin kalkınma adına uyguladıkları politikalarda çevreyi içine alan kararlar almaları beklenmektedir (Schiederig vd., 2012, s. 180). Kentsel politikalar toplumsal talepler doğrultusunda şekillendiğinden, kentsel inovasyon sürecinde kullanılacak teknolojilerin seçiminde çevre duyarlılığı ön planda olan faaliyetlerin kamu otoritelerinden talep edilmesi sonucunda çevreyle ilgili yeni düzenlemeler yapılmakta ve kentler şekillenmektedir. Rekabet edebilen, sürdürülebilir, teknolojik kentler yaratmak için atılacak adımlarda çevreye duyarlı projelerin uygulanması kentleri rakipleri karşısında öne geçirmektedir (Demiral, 2005, s. 252). Kentsel inovasyon, alışkanlıklarda değişim yaratarak çevre, sosyal yaşam ve ekonomide kalıc yaşam tarzı farklılaşmalarına yol açtı̆̆ından yerel yönetimler ve şehir planclları kentsel inovasyonun önemini ihmal etmemelidirler (Goi, 2017, s. 9-10). Kentsel inovasyonla aktif çevre politikalarımüdahaleleri (atık yönetimi, iyileştirme-temizleme çalışmaları, vb.gibi), sahip olunan kaynakların iyileştirilmesi ve teknolojik altyapının geliştirilerek sağlık, eğitim ve sosyal yaşam alanları başta olmak üzere sosyal ölçü ve refah göstergelerinin iyileştirilmesi ve sürdürülebilirlik hedeflenmektedir (Macomber, 2013, s. 40-41).

\section{Yöntem}

Mekânsal ekonometri, mekanlar arasındaki ilişki yapısını (etkileşimi) göstererek mekânsal etkileri ortaya çıkarmayı amaçlamaktadır. Konum/mesafe ile ilişkili olabilen bağımlılık yapısı, coğrafi/ekonomik/sosyal alanda ortaya çıkabildiğinden davranış biçimlerini açıklamada kullanılabilmektedir (Elhorst, 2011, s. 2) Baz alınan konuma bağlı olarak ortaya çıkan ve baz alınan konum ile komşu konum arasındaki ilişkiyi tanımlayan mekânsal etki, yatay kesit bağımlılığı kapsamında komşu konumdaki korelasyonu ifade eden mekânsal bağımlılığa (otokorelasyon) ve yatay kesit heterojenliği kapsamında ilgilenilen değişkenin bir konumdan diğerine sabit olmayan varyansını ifade eden mekânsal heterojenliğe sahip olabilmektedir (Anselin vd., 
2008, s. 5). Mekânsal birimlerin homojenlikten uzaklaşmasına neden olan mekânsal heterojenlik, ilgilenilen alan üzerindeki noktalarda farklı ilişkinin gözlenmesi olarak tanımlanmaktadır. Doğrusal regresyon modelinde, $i=1$, $2, \ldots, n$ gözlemleri için $(1 \times K)$ boyutlu açıklayıcı değişken matrisi $x_{i}$, bağımlı değişken vektörü $y_{i}$, parametre vektörü $\beta_{i}$ ve hata terimi $\varepsilon_{i}$ olmak üzere mekânsal heterojenlik $y_{i}=f_{i}\left(x_{i} \beta_{i}, \varepsilon_{i}\right)$ şeklinde gösterilmektedir (Lesage, 1999, s. 7). Rassal değişkenin komşu konumlarda gözlenen değerleri arasındaki korelasyonun sıfırdan farklı olması mekânsal otokorelasyon olarak tanimlanmaktadır (Darmofal, 2006, s. 6). i ve $j$ konumları arasındaki korelasyona $\operatorname{Cov}\left(y_{i}, y_{j}\right)=E\left(y_{i} y_{j}\right)-E\left(y_{i}\right) E\left(y_{j}\right) \neq 0, \forall i \neq j$ ifadesi ile ulaşlabilmektedir. $i$ ve $j$ konumları arasındaki korelasyon sıfırdan farklı ise mekânsal açıdan ilişki (değer benzerliği ile konum benzerliğinin uyumlu) olduğu söylenebilmektedir. Şekil 1.'de rassal değişken için düşük/yüksek olan değerlerin kümelenme eğiliminde olduğu pozitif mekânsal otokorelasyon (1) ve baz alınan konumun komşu konumlar tarafından çok farklı değerler ile çevrelenmiş olduğu negatif mekânsal otokorelasyon (2) gösterilmektedir. Rassallık durumunda (3) ise değer dağılımları belirli bir kalıba uymamakta ve mekânsal otokorelasyondan söz edilememektedir (Viton, 2010, s. 3).

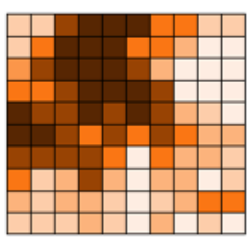

(1)

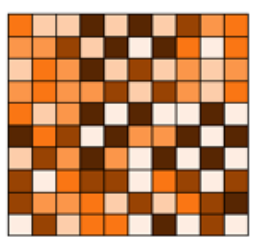

(2)

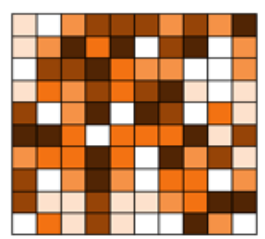

(3)

Şekil 1. Mekânsal Otokorelasyon Tabloları (Kaynak: Tatlı,2016,s.11)

Mekânsal ekonometride konumdan kaynaklı ilişki yapısı coğrafi ağırlıklandırma veya sosyo-ekonomik ağırlıklandırma teknikleriyle matris formu kullanılarak gösterilmektedir. Makale kapsamında ele alınan birim, iller düzeyinde mekânsal yapıya sahip olduğundan mekânsal ağırlıklandırma tekniği olarak coğrafi tekniklerin kullanımı tercih edilmektedir. İlgilenilen birimlerin özelliğine göre ortak sınır paydaşlı̆̆ı veya belli bir mesafedeki gözlemlerin mekânsal düzenlemesine dayanan coğrafi ağırlıklandırma, sınırdaşlığa ve uzaklığa bağlı olarak oluşturulmaktadır. (Anselin ve Bera, 1998, s. 243) Uzaklığa bağlı ağırlıklar, mekânsal birimler arasındaki ortak sınırın nispi uzunluğuna ya da bu birimler arasındaki mesafeye göre belirlenen uzaklık azalan fonksiyonla gösterilmektedir (Anselin, 1988, s. 20). Sınırdaş olmayan birimler kullanıldığında, enlem-boylam temelli mesafeye dayalı komşuluğun 
kullanımı tercih edilmektedir. $i$ ve $j$ birimleri arasındaki mesafeyi $d_{i j}$ göstermek üzere uzaklığa dayalı ağırlık matrisi $w_{i j}=f\left(d_{i j}\right)$ şeklinde ifade edilebilmektedir. Sınırdaşlığa bağlı ağırlıklandırmada mekânsal birimler arası ilişki, sınırların ayırt edilebilir harita üzerinden konuma dayalı olarak belirlenmesiyle oluşturulmaktadır. Şekil 2'de, ortak sınıra sahip alanlar ve birbirini çevreleyen alanlar için bitişik alanların ortak kenar paylaşması üzerine kurulan kale komşuluğu (1), bitişik alanların ortak bir köşe paylaşması üzerine kurulan fil komşuluğu (2), bitişik alanların ortak bir kenar ve köşe paylaşması üzerine kurulan vezir komşuluğu (3) olmak üzere üç komşuluk tanımı gösterilmektedir.
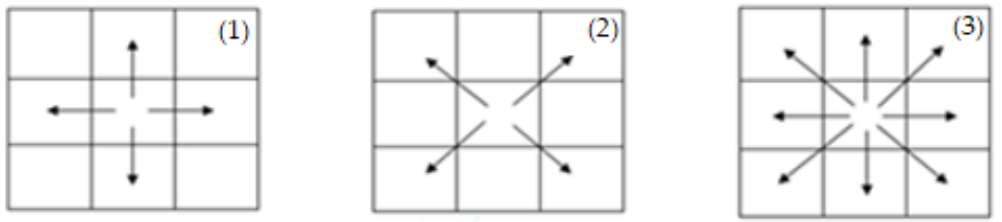

Şekil 2. Komşuluk Çeşitleri (Kaynak: Tatlı, 2016, s. 11)

Mekânsal veri analizinde gözlemler arasında mekânsal bağlllık modellendiğinden her bir gözlemin bir dizi komşu gözlemle bağlantılı olduğu dışsal mekânsal kalıba uygun mekânsal ağırlık matrisi oluşturulmaktadır. $N \times N$ boyutlu pozitif mekânsal komşuluk matrisinin $(\widetilde{W})$ satır elemanı i konumu ile sütun elemanı $\mathrm{j}$ konumu arasındaki etkileşimin gücü, $\widetilde{w}_{i j}$ elemanıyla gösterilmektedir. Gözlemler arasındaki ilişkinin gücü mekânsal ağırlık yapısı ile ifade edilmektedir. i ve $\mathrm{j}$ konumları komşu ise $\widetilde{w}_{i j}=1$, komşu değiller ise $\widetilde{w}_{i j}=0$ olarak elde edilmektedir (Lesage, 1999, s. 11). Satır standartlaştırılmış komşuluk matrisi mekânsal ağırlık matrisi $\left(w_{i j}=w_{i j} / \sum_{j} w_{i j}\right)$ olarak adlandırılmaktadır. Simetrik olan mekânsal komşuluk matrisi simetrik olmayan bir yapıya dönüşmektedir (Viton, 2010, s. 5). Mekânsal olmayan doğrusal regresyon modeli kurulduktan sonra modelin mekânsal etkiyle genişletilmeye ihtiyacı olup olmadığı test edilmektedir. Gözlemlerin bağımsız olduğu varsayımı, hata terimleri arasındaki mekânsal bağımlılıktan dolayı uygun olmamaktadır. Mekânsal bağımlılık; mekânsal korelasyona dayanan mekânsal gecikme bağımlılığı ve hata teriminde gözlenen mekânsal korelasyona dayan mekânsal hata bağımlılığı olarak iki farklı yapıda görülebilmektedir. İlişki yapısının farklı şekillerde gözlemlenmesi mekânsal model spesifikasyonları arasında ayrım yapılmasını kolaylaştırmaktadır. Şekil 3'te mekânsal model- 
lere ilişkin özet bilgiler yer almaktadır. Mekânsal gecikme (SAR) modeli bağımlı değişkendeki mekânsal korelasyonu açıklamakta ve bu model spesifikasyonu, komşuluk etkisinin önemini vurgulayarak bağımlı değişkendeki görülen mekânsal dışsallığa dayanmaktadır. Mekânsal (SEM) hata modeli, hata terimindeki mekânsal bağımlılığı açıklamakta ve gözlenemeyen gizli değişkenlerin mekânsal korelasyonlu olması durumundan toplanan değişkenlerin komşuluk yapısını doğru yansıtmaması durumunda ortaya çıkabilmektedir. Veriler arasında mekânsal açıdan ilişki (yayılma etkisi) yoksa model tahmininde standart yöntemler kullanılabilirken; mekânsal yapı belirlendiğinde standart tahmin yöntemlerinin kullanımı sapmalı-tutarsız tahminlere neden olduğundan mekânsal ilişkiyi dikkate alan yöntemler kullanılmaktadır (Gumprecht, 2007, s. 10). Mekânsal modeller için kullanılan tahmin yöntemleri arasında en çok olabilirlik yöntemi, genelleştirilmiş momentler ve araç değişkenler tahmin yöntemi yer almaktadır. En çok olabilirlik tahmininde, olabilirlik fonksiyonundan hatalar için birleşik normal yoğunluk türetilmektedir. $\rho$ ve $\lambda$ mekânsal otoregresif katsayılar ve $W$ mekânsal ağırlık matrisi iken $|I-\rho W|$ ve $|I-\lambda W|$ sirasiyla mekânsal gecikme ve mekânsal hata modeli şeklini almaktadır. Mekânsal gecikme modelinde, mekânsal gecikmeli bağımlı değişkenle ( $W y$ ) hata terimi arasında içsellik söz konusu olduğunda araç değişkenler önerilmektedir (Anselin, 1990, s. 141).

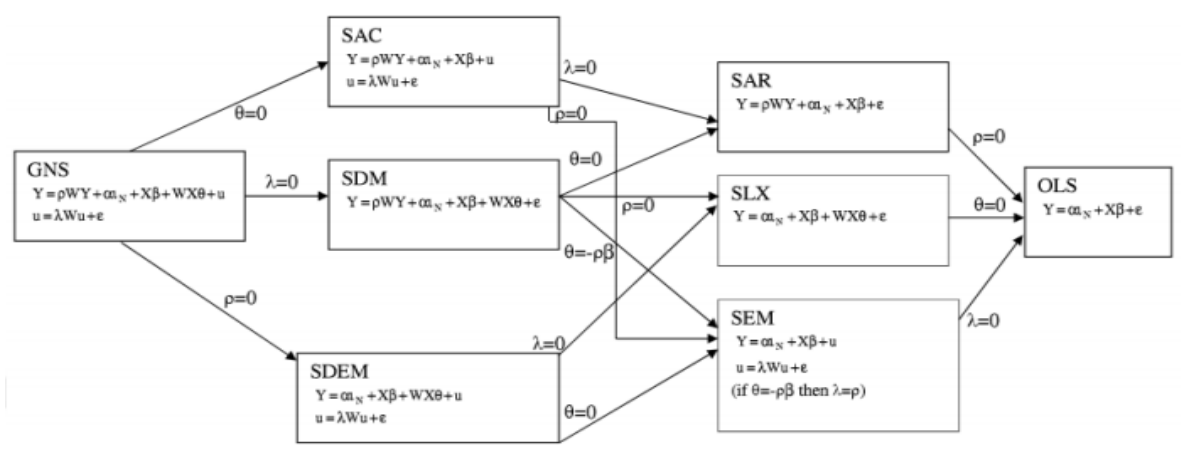

Şekil 3. Mekânsal Modeller(GNS:yuvalanmış mekânsal model,SAR:mekânsal gecikme modeli,SEM:mekânsal hata modeli,SDM:mekânsal Durbin model,SAC: genel mekânsal model,SLX:bağımsız değişkeni mekânsal gecikmeli model ve SDEM:mekânsal Durbin hata modeli) (Kaynak: Tatlı ,2016, s. 22)

Mekânsal modellerde kullanılan istatistikler global istatistikler (Moran I, Geary C ve Getis-Ord G istatistiği) ve lokal istatistikler (Moran I ve lokal Getis-Ord G istatistiği) olarak ayrılmaktadır. Mekânsal modeller için kullanılan 
diğer testler ise Kelejian-Robinson testi, mekânsal hata otokorelasyon testi, mekânsal gecikme bağımlılık testi, mekânsal hata gecikme bağımlılığının birlikte testi ve lokal tanımlama hatası varlığında dirençli testler olarak sıralanabilmektedir. Mekânsal ekonometride spesifikasyon testlerinin temelini Moran otokorelasyon testleri oluşturmaktadır. Mekânsal bağımlılık için DurbinWatson testiyle ilişkili olan Moran I testi kullanılmaktadır. Moran I testi, mekânsal bağımlılık türlerinin çoğunluğuna karşı güçlü bir yapıya sahipken, alternatif hipotezler bağımlılık yapısının tüm türleri için geliştirilmemiştir. Mekânsal otokorelasyon düzeyini test etmek ve ölçmek için kullanılan Moran I istatistiği, mekânsal stokastik süreçte mekânsal otokorelasyonun şiddetini ölçmektedir. Standardize edilmiş mekânsal bağlantı matrislerinde de kullanılmaktadır. Moran I testi, mekânsal otokorelasyon düzeyi $\rho$ 'nun anlamlıllğını sınamak için kullanılan parametrik testir. Moran I serpilme diyagramı, Moran I istatistiği yardımıyla otokorelasyonu geometrik olarak göstermek için kullanılan tanısal bir araçtır. Saçılım diyagramı olan Moran grafiği, y değişkeni ile y'nin mekânsal gecikmesi arasındaki ilişkinin grafiksel sunumudur. Genellikle satır standartlaştırılmış mekânsal ağırlık matrisi kullanılmaktadır (Gumprecht, 2007, s. 16). Kelejian-Robinson testi ise mekânsal gecikme ya da mekânsal hata bağımlılığı şeklinde kurulan alternatif hipotezin testine odaklanmaktadır. İki tür otokorelasyon yapısı için geçerli olan testler asimptotik olarak bağımsız olmadığından testlerin ayrı ayrı uygulanması testlerin güvenilirliklerini azaltırken, yokluk hipotezin reddedilmesi halinde bağımlılık yapısı hakkında bilgi sahibi olunamamaktadır. Bu nedenle, mekânsal gecikmeli model tahmin edildikten sonra mekânsal hata korelasyonu için test gerçekleştirilmektedir. Lokal istatistikler (LISA), her bir konum için ayrı bir katsayı türeten istatistiklerdir. Her gözlem için LíSA, gözlemlerin etrafında benzer değerlerin belirgin mekânsal kümelenmesinin ölçümünü vermektedir. Tüm gözlemler için LİSA'ların toplamı mekânsal bağımlılığın global istatistiğini vermektedir. LISA istatistikleri içinde en çok lokal Moran I istatistiği kullanılmaktadır. Mekânsal bağımlılığın lokal Moran I istatistik değerinin pozitif olması, bir konumun yüksek ya da düşük değerler açısından kendisiyle benzeşen komşulara sahip olduğunu göstermekte ve bu durum kümelenmeyi ifade etmektedir. Mekânsal hata otokorelasyonunun testinde ise alternatif hipotez, $\varepsilon=\lambda W \varepsilon+\xi$ veri yaratma süreciyle, belirlenmektedir. $\lambda=$ 0 yokluk hipotezinin testinde LR, LM ve Wald ve regresyon modelinin LS tahminine dayanan RS testi kullanılabilmektedir. Mekânsal gecikme bağımlılığının ortaya çıkartılması için $\rho=0$ yokluk hipotezinin testinde log-olabilirlik fonksiyonundan yararlanılmakta ve bağımlık yapısının test edilmesi 
için RS testi kullanılabilmektedir. Mekânsal hata ve gecikme bağımlılı̆̆ını birlikte ortaya çıkarmaya yarayan testler ise tek yönlü test olarak adlandırılmakta ve modelin kalıntısının doğru spesifikasyonda olduğu varsayımı altında, tek bir spesifikasyonu test etmek için kullanılmaktadır. Genel tanımlama hatasının varlığı halinde testleri dirençli hale getirmek mümkün olmazken, lokal tanımlama hatası için dirençli testler gerçekleştirilebilmektedir (Bera ve Yoon, 1993, s. 649).

Makale kapsamında ele alınan patent başvurusu ile faydalı model sayısı, kişi başına düşen ortalama atık miktarı, orman alanı, nitelikli yatak sayısı, fiber optik kablo uzunluğu ve konut satış sayısı (sahipliği) değişkenleri yayılma etkisi yaratarak dışsallık oluşturma eğiliminde olduklarından; ağırlık matrislerinin oluşturulmasında, otokorelasyonun varlığının araştırılmasında, aykırılıkların/kümelenmelerin belirlenmesinde ve dağılımların görselleştirilmesinde mekânsal modellerden faydalanılarak kentsel inovasyon göstergelerinin kentleşme üzerindeki mekânsal etkisinin ortaya çıkartılması amaçlanmaktadır.

\section{Bulgular}

Sağlık sektörüne yapılan yatırımlar kapsamında il bazında hastanelerde bulunan nitelikli yatak sayısı, çevresel faaliyet göstergeleri olarak il bazında kişi başına düşen ortalama atık miktarı ve il bazında orman alanı, teknolojik altyapı harcamaları kapsamında il bazında fiber optik kablo uzunluğu, araştırma-geliştirme faaliyetleri kapsamında il bazında patent başvurusu ile faydalı model sayısı ve bireyler tarafindan yapılan uzun vadeli tasarruf kapsamında il bazında konut satış sayısı olarak ele alınan kentsel inovasyon göstergelerinin, kentte ikamet eden nüfusun değişim sürecini gösteren kentleşmeye olan etkisinin ortaya çıartılması amaçlanmaktadır. Düzeyde üstel bir büyüme ve azalış gösteren serilerde ortaya çıan aşırı değişimi dengelemek için serilerin logaritması alınarak değişimlerin doğrusal bir formda ifade edilmesi sağlanmaktadır.2018 yılı baz alınarak Türkiye Sağlık Bakanlığı 2018 Sağlık İstatistikleri Raporu, Türkiye İstatistik Kurumu (TÜİK), Bilişim Teknoloji Kurumu (BTK), Türkiye Patent Enstitüsü (TPE) ve Tarım ve Orman Bakanlığı'ndan elde edilen değişkenler ve betimleyici istatistikler Tablo 2' de yer almaktadır. Makale kapsamında kullanılan değişkenlerin seçiminde 2018 yılına ait il bazında veri setine ulaşılabilirlik belirleyici olmaktadır. 
Tablo 2. Modelde kullanılan değişken tanımları ve betimleyici istatistikler

\begin{tabular}{|c|c|c|c|c|}
\hline \multirow{2}{*}{$\begin{array}{l}\text { KO } \\
\text { NYS } \\
\end{array}$} & \multicolumn{4}{|c|}{$\begin{array}{l}\text { Kentleşme Oranı (20.001 ve üzeri nüfusa sahip yerleşim yerlerinde } \\
\text { yaşayan nüfusun toplam nüfusa oranı) }\end{array}$} \\
\hline & \multicolumn{4}{|c|}{ İl Bazlı Nitelik Yatak Sayısı } \\
\hline AM & \multicolumn{4}{|c|}{ Kişi Başına Düşen Ortalama Atık Miktarı (kg/kişi) } \\
\hline KS & \multicolumn{4}{|c|}{ Konut Satış Sayısı } \\
\hline FKU & \multicolumn{4}{|c|}{ Fiber Optik Kablo Uzunluğu } \\
\hline $\mathbf{P}$ & \multicolumn{4}{|c|}{ Patent ve Faydalı Model (İl Bazında Patent ve Faydalı Model Başvuru sayısı) } \\
\hline \multirow[t]{2}{*}{ OA } & \multicolumn{4}{|c|}{ Orman Alanı (hektar) } \\
\hline & Ortalama & Standart Sapma & Minimum Değer & Maksimum Değer \\
\hline KO & 0,6869 & 0.23478 & 0,22 & 0,99 \\
\hline NYS & 6.89453 & 1.023883 & 4.682131 & 10.01135 \\
\hline AM & 1,1593 & 0,26533 & 0.98 & 2,01 \\
\hline KS & 8.993555 & 1.278198 & 5.068904 & 12.36331 \\
\hline FKU & 8.018478 & 0.758450 & 6.522093 & 10.76682 \\
\hline $\mathbf{P}$ & 2.957900 & 1.736284 & 0 & 8.373091 \\
\hline OA & 12.04055 & 1.309025 & 5.081404 & 13.95184 \\
\hline
\end{tabular}

Kentleşme oranına $(\mathrm{KO})$ ilişkin dağılım genişliği baz alınarak 5 parçaya ayrılan mekânsal dağılım haritası Şekil 4 'te gösterilmektedir. En yüksek kentleşme oranı \% 99 iken en düşük kentleşme oranın \%22 olduğu tespit edilmektedir. Düşük kentleşmenin olduğu yerler açık renk ile gösterilirken kentleşme oranındaki artışa göre illerin renkleri koyu olarak gösterilmektedir. İller bazında kişi başı ortalama atık miktarı (AM), fiber optik kablo uzunluğu (FKO), konut satış sayısı (KS), nitelikli yatak sayısı (NYS), orman alanı (OA) ve patent ve faydalı model sayısı (P) değişkenlerinin mekânsal etki taşıyıp taşımadığı hakkında ön bilgi veren mekânsal dağılım haritası Şekil 5'de verilmektedir.

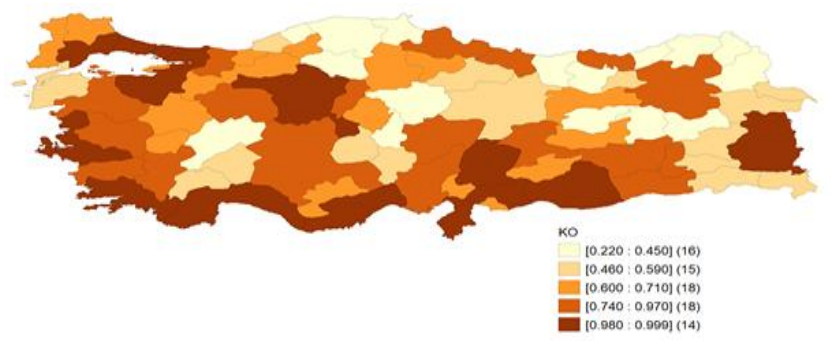

Şekil 4. Kentleşme Oranına İlişkin Mekânsal Dağılım Haritası

Mekânsal dağılım haritaları incelendiğinde ilgili değişkenlerin dağılımının rassal olmadığ görülmektedir. AM, FKO, KS, NYS, OA ve P'ye ilişkin mekânsal dağılım haritası 5 parçaya ayrılmıştır. En düşük atık miktarı 0.75 kilogram iken en yüksek atık miktarı 2.01 kilogram, en düşük fiber optik 
kablo uzunluğu 680 metre iken, en uzun fiber optik kablo uzunluğu 47.421 metre, en düşük konut satış miktarı 159 adet iken, en yüksek konut satış miktarı 234.055 adet, en düşük nitelikli yatak sayısı 108 adet iken en yüksek nitelikli yatak sayısı 22278 adet, en düşük orman alanı 161 hektar iken en yüksek orman alanı 1.146.062 hektar, en düşük patent-faydalı model başvuru sayısı 1 adet iken en yüksek başvuru sayısı 3342 adet olarak elde edilmektedir.

Açik renkten koyu renge doğru gidildikçe atık miktarında, fiber optik kablo uzunluğunda, konut satışlarında ve patent sayılarında artış görülmektedir. Koyu renge sahip kentlerde atık miktarının fazla olduğu, teknolojik altyapının sağlandığı, nitelikli yatak sayısına sahipliğin fazla olduğu ve patentfaydalı model başvurusunun fazla olduğu gözlemlenmektedir. Ek olarak, batı bölgesinde yer alan illerin birçoğunda ormanlaşma alanı ortalamanın üzerinde iken, doğu bölgesinde yer alan illerin birçoğunda ve İç Anadolu bölgesinde bulunan illerin bazılarında yeteri düzeyde orman alanı sahipliği bulunmamaktadır.

Mekânsal dağılım haritası incelenen verilerin iller bazında dağılımını gösterilmekle birlikte mekânsal ilişkinin anlamlılığı, yönü ve gücü hakkında bilgi sunmaktadır. Bu nedenle Şekil 6'da kentleşme oranı değişkeni için LISA haritası ve Moran I serpilme diyagramları verilmektedir. LISA haritasında yer alan ve beyaz ile işaretlenen alanlar iller arasında mekândan kaynaklı anlamlı bir korelasyon olmadığı yani kentleşme olgusu olmasına rağmen mekânsal etkiden kaynaklanmadığını göstermektedir.

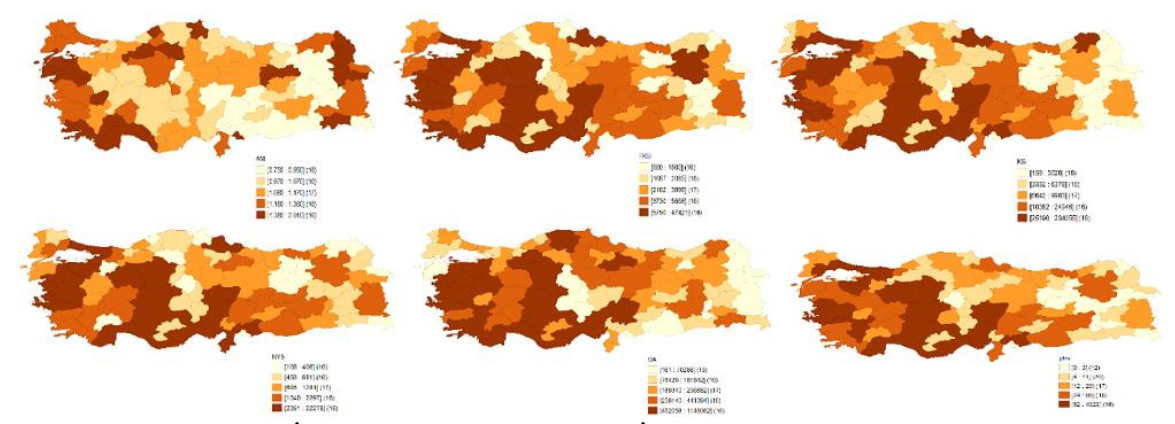

Şekil 5. Kentsel İnovasyon Göstergelerine İlişkin Mekânsal Dağılım Haritaları

LİSA haritasında kırmızı ile işaretlenen alanlar, mekânsal kümelenmeyi göstermekte ve ilişkinin derecesinin "yüksek-yüksek" olduğu illeri ifade etmektedir. Moran I serpilme diyagramının 1. bölgesinde yer alan yüksek-yüksek ilişki derecesine sahip olan illerin kentleşme oranı yüksek iken, komşularındaki kentleşme oranı da yüksek olmaktadır. LISA haritasında pembe ile 
işaretlenen alanlar, mekânsal kümelenmeyi göstermekte ve ilişkinin derecesinin "yüksek-düşük" olduğu illeri ifade etmektedir. Moran I serpilme diyagramının 2. bölgesinde yer alan yüksek-düşük ilişki derecesine sahip olan illerin kentleşme oranı yüksek iken, komşularındaki kentleşme oranı düşük olmaktadır.
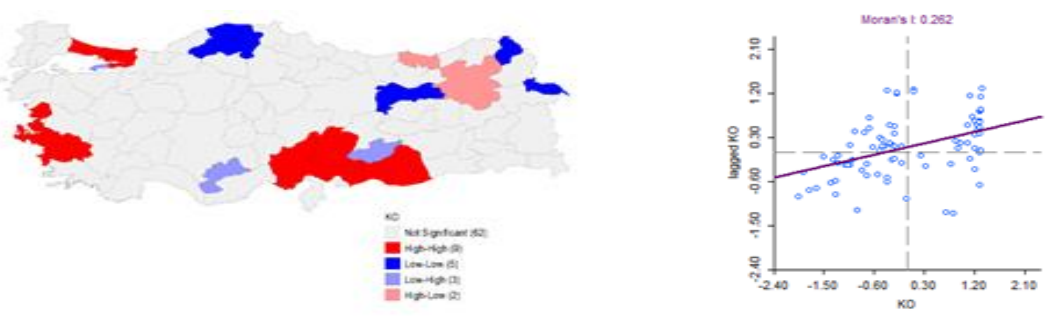

Şekil 6. Kentleşme Oranına ait LISA Haritası ve Moran I Serpilme Diyagramı

LISA haritasında mavi ile işaretlenen alanlar, mekânsal kümelenmeyi göstermekte ve ilişkinin derecesinin "düşük-düşük" olduğu illeri ifade etmektedir. Moran I serpilme diyagramının 3. bölgesinde yer alan düşük-düşük ilişki derecesine sahip olan illerin kentleşme oranı düşük iken, komşularındaki kentleşme oranı düşük olmaktadır. LíSA haritasında lacivert ile işaretlenen alanlar, mekânsal kümelenmeyi göstermekte ve ilişkinin derecesinin "düşükyüksek" olduğu illeri ifade etmektedir. Moran I serpilme diyagramının 4. bölgesinde yer alan düşük-yüksek ilişki derecesine sahip olan illerin kentleşme oranı düşük iken, komşularındaki kentleşme oranı yüksek olmaktadır. Tablo 2'de LISA haritasındaki anlamlı korelasyona sahip iller gösterilmektedir.

Tablo 3. LISA haritasına göre anlamlı korelasyona sahip iller

\begin{tabular}{ll}
\hline Yükssek-Yüksek & $\begin{array}{l}\text { İstanbul, Kocaeli, İzmir, Aydın, Adana, Osmaniye, Gaziantep } \\
\text { Kahramanmaraş, Şanlıurfa }\end{array}$ \\
\hline Yüksek -Düşük & Erzurum, Trabzon \\
\hline Düşük - Düşük & Kastamonu, Karabük, Erzincan, Ardahan, Iğdır \\
\hline Düşük- Yüksek & Yalova, Karaman, Adıyaman \\
\hline
\end{tabular}

Kentleşme oranına ilişkin korelasyonun anlamlı olduğu iller incelendiğinde, Doğu ve Güneydoğu bölgelerinin sınır illerinde, Ege, Marmara ve Karadeniz bölgelerinin kıyı illerinde belirgin kümelenme görülmektedir. Kentleşme oranı için oluşturulan Moran I serpilme diyagramından bağımlı değişkende ön bilgi olarak belirgin pozitif mekânsal otokorelasyonun söz konusu olduğu görülmektedir. Mekânsal otokorelasyonu varlığını sorgulayan yok- 
luk hipotezi \%1 önem düzeyinde (pseudo p-değeri 0.003<0.01) reddedildiğinden mekânsal otokorelasyonun olduğu ve Moran I istatistiği (0.2661) pozitif olarak tespit edildiğinden, pozitif otokorelasyonun var olduğu yani kentsel inovasyonun pozitif yönde mekânsal bir yapı sergilediği söylenebilmektedir.
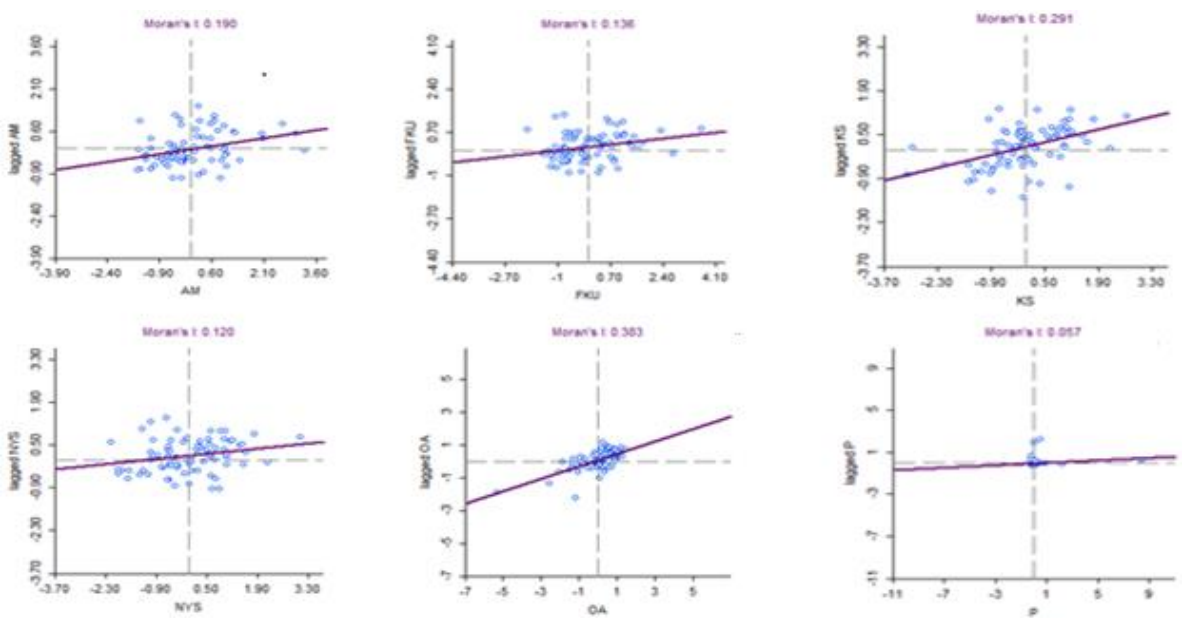

Şekil 7. Kentsel inovasyon göstergelerine ilişkin Moran I serpilme diyagramı

Şekil 7'de kentsel inovasyon göstergeleri için kullanılan ilgili değişkenlere ait Moran I serpilme diyagramları görülmektedir. Mekânsal otokorelasyonun varlığını sorgulayan yokluk hipotezleri \%1 önem düzeyinde reddedildiğinden ve Moran I istatistik değerleri pozitif olduğundan ilgili değişkenlerin pozitif yönlü mekânsal otokorelasyona sahip olduğu söylenebilmektedir. Tablo 4'te kentsel inovasyonun kentleşme üzerindeki etkisinin ve kentleşmenin mekânsal dağılımının araştırılması için kurulan model ve en küçük kareler (EKK) ile en çok olabilirlik (ML) tahmini kullanılarak uygun mekânsal modele karar verilmesi için elde edilen tanımlayıcı test istatistikleri gösterilmektedir.

Gözlenen mekânsal yapının hangi etkiden kaynaklandığını belirlemek amacıyla, modelin kalıntıları kullanılarak yapılan belirleyici test sonuçları Tablo 4'te gösterilmektedir. Uygun bağımlılık yapısına karar vermek için kullanılan testlerden $L M_{\rho}$ mekânsal gecikme bağımlılığını ve $L M_{\lambda}$ mekânsal hata bağımlılığını göstermektedir. İki testin en genel hali olan $L M_{\rho \lambda}$ ise her iki bağımlılığın birlikte var olup olmadığını belirlemek için kullanılmaktadır. 
Tablo 4. Kentsel İnovasyon Göstergelerinin Kentleşme Oranına Etkisi

\begin{tabular}{|c|c|c|c|c|}
\hline & EKK Tahmini & SAR Tahmini & \multicolumn{2}{|c|}{ Tanımlayıcı istatistikler } \\
\hline W_KO & - & $\begin{array}{l}0.26532^{* * *} \\
(0.105739)\end{array}$ & Moran I (hata) & $1.9923^{* *}$ \\
\hline Sabit Terim & $\begin{array}{l}-0.78754 \\
(0.0906) \\
\end{array}$ & $\begin{array}{l}-0.90706^{*} \\
(0.108946) \\
\end{array}$ & $L M_{\lambda}$ & 2.2411 \\
\hline NYS & $\begin{array}{l}0.08326^{*} \\
(0.4742)\end{array}$ & $\begin{array}{l}0.07699^{* *} \\
(0.4292)\end{array}$ & $L M_{\rho}$ & $7.2934^{* * *}$ \\
\hline AM & $\begin{array}{l}-0.10325 \\
(0.0753)\end{array}$ & $\begin{array}{l}-0.10799^{*} \\
(0.067)\end{array}$ & Robust $L M_{\lambda}$ & 1.1664 \\
\hline KS & $\begin{array}{l}0.06480^{* * * *} \\
(0.29634) \\
\end{array}$ & $\begin{array}{l}0.05137^{* *} \\
(0.26644) \\
\end{array}$ & Robust $L M_{\rho}$ & $5.2188^{* *}$ \\
\hline FKU & $\begin{array}{l}0.08322 \\
(0.22093)\end{array}$ & $\begin{array}{l}0.10005^{*} \\
(0.19876)\end{array}$ & $L M_{\rho \lambda}$ & 7.4599 \\
\hline $\mathbf{P}$ & $\begin{array}{l}-0.00009^{* *} \\
(0.0001)\end{array}$ & $\begin{array}{l}-0.00010^{* * * *} \\
(0.000124)\end{array}$ & & \\
\hline OA & $\begin{array}{l}-0.01844 \\
(0.10049) \\
\end{array}$ & $\begin{array}{l}-0.02083^{*} \\
(0.9015) \\
\end{array}$ & & \\
\hline & $R^{2}=0.672153$ & $R^{2}=0.701352$ & & \\
\hline
\end{tabular}

$L M_{\rho \lambda}$ 'ye ilişkin yokluk hipotezi istatistiksel olarak reddedildiğinden mekânsal etkiler tek tek sınanmaktadır. Mekânsal hata bağımlılığına $\left(L M_{\lambda}\right)$ ilişkin yokluk hipotezi istatistiksel olarak reddedilirken mekânsal gecikme bağımlılığına $\left(L M_{\rho}\right)$ ilişkin yokluk hipotezi istatistiksel olarak kabul edildiğinden, mekânsal gecikme etkisinin var olduğu sonucuna ulaşılmaktadır. Mekânsal gecikme modeli (SAR) sonuçları Tablo 4'te verilmektedir. OA, AM ve $P$ değişkenlerinin kentleşme üzerindeki etkisi negatif ve istatistiksel olarak anlamlıyken, NYS, KS ve FKO değerlerinin kentleşme üzerindeki etkisi pozitif ve istatistiksel olarak anlamlı bulunmaktadır. Mekânsal bağımlılık göstergesi olan $\mathrm{W} \_\mathrm{KO}(\rho)$ \%1 önem düzeyinde istatistiksel olarak anlamlı bulunmaktadır. Mekânsal gecikme terimi $(\rho)$ pozitif olması bir konumda kentleşme eğilimi ne yönde ise o konumun komşularında da ayn yönde olacağını ifade etmektedir. Diğer bir ifadeyle, her bir il için verilen kentleşme oranının ilgili kentsel inovasyon göstergelerinden etkilenmesinin yanı sıra komşu illerdeki kentleşme oranından da etkilendiği söylenebilmektedir.

\section{Tartışma ve Sonuç}

Kentsel inovasyon faaliyetleri, gelişmekte olan ülkelerde sürdürülebilir kentsel kalkınmanın sağlanmasına yardımcı olmaktadır. Kentlerin hem içyapıla- 
rında hem de nüfus, kapital ve faaliyet dağılımının mekânsal farklılaşmasında önemli değişmeler yerleşme kademelerinde (tek merkezli metropollerin kentsel dönüşümle birlikte bilgi toplumunun çok merkezli kent bölgeleri haline gelmesi) gözlemlenmektedir Gelişmiş ülkelerde kentsel inovasyonun başarılı örnekleri bulunmakla birlikte, gelişmekte olan ülkeler kentsel inovasyon için kullandıkları teknolojiyi gelişmiş ülkelerden satın alarak akıllı kent yaratma çabasındadırlar. Makale kapsamında, gelişmekte olan ülkeler sınıfında olan ve kalkınma odaklı bir politika izleyen Türkiye'de kentsel innovasyon göstergesi olarak alınan değişkenlerin kentleşme üzerindeki etkisinin ortaya çıkartılması ve iller-arası etkileşimin olabilirliği varsayımıyla kentleşmede mekânsal etkiden söz edilebilirliğin araştırılması amaçlanmaktadır. İller bazında, kentsel inovasyon göstergeleri ve kentleşme açısından homojenlik yapısının varlığı sorgulanmaktadır. Bu çerçevede, patent başvurusu ile faydalı model sayısı, kişi başına düşen ortalama atık miktarı, orman alanı, nitelikli yatak sayısı, fiber optik kablo uzunluğu ve konut satış sayısı (sahipliği) ele alınmaktadır. Türkiye'de kentleşme düzeyinde ciddi farklılık olduğu, ülkenin batı ve doğu bölgesindeki illerin birbirinden farklı özellikler gösterdiği ve kendi içlerinde heterojen bir yapı göstererek mekânsal etkileşim içinde oldukları tespit edilmiştir.

Toplumlardaki yapısal değişimler konut algısını değiştirmektedir. Türkiye'de orta-dar gelir grupları için sosyal güvence ve üst gelir grubu için tasarruf/yatırım aracı olarak görülen konut sahipliğindeki artışın kentleşme üzerine istatistiksel olarak anlamlı ve pozitif yönde etkisi belirlenmektedir. Kent yapısındaki eşitsizlikler ve çarpıklıklar ülkeyi etkilediğinden kentleşme politikalarında konut politikaları önemli olmaktadır. Tekeli (2016)'ya göre, sanayileşme ile ortaya çıkan nüfus artışı ve konut ihtiyacı kentleri yapısal olarak değiştirirken, yerleşim alanlarında bozuk kentleşmelere neden olmaktadır. Sanayi ve kentleşmenin doğru orantılı gerçekleştiği ülkelerin aksine, Türkiye'de kentlerin çekiciliğinden çok kırsal kesimin iticiliğinden/yoksunluğundan göç olgusunun meydana geldiğini ve kültürel etkileşim sorunu yaşanmasının yanı sıra modernitenin meşruiyet kalıpları içinde göç edenlerin kente yerleştirilme sorunun "gecekondulaşma" ile çözülmesi sonucunda kentlerin çevresinde oluşan büyük gecekondu kuşaklarının, büyük metropollerin merkezlerini desantralize ederek tek hâkim merkezli kentsel yapının yerini çok odaklı kent bölgelerinin aldığını belirtmektedir (Tekeli, 2016, s. 1819). Birleşmiş Milletler Sürdürülebilir Kalkınma hedefleri çerçevesinde, bugün ve gelecek nesillerin mutluluğunu amaçlayan "mutluluk ekonomisi" 
adıyla insanı ön plana çkartan ve çevrenin korunmasına odaklanan politikalar ortaya konmaktadır. Gelişmiş sanayi ülkeleri bu politikanın uygulanmasının erken olduğunu belirtmekle birlikte, sürdürülebilir kalkınma politikalarını uygulayarak üretim maliyetlerini arttırmaktadır (Soplop, vd., 2009, s. 3557). Bununla birlikte, Türkiye gibi gelişmekte olan ülkelerde kıt kaynakların ve çevresel bozulmanın sürdürülebilir kalkınma üzerinde yarattığı ekonomik ve sosyal maliyet göz ardı edilerek sanayileşme, ekonomik büyüme ve gelir artışı olgusu ön plana çıkmaktadır. Türkiye'de ortalama atık miktarlarının ve orman alanının kentleşme üzerine istatistiksel olarak anlamlı ve negatif yönde etkisi belirlenmektedir.

Sosyal ve ekonomik gelişmenin koşulları arasında yer alan sanayileşme ve sürdürülebilir kalkınmaya paralel olarak ortaya çıkan kentleşme, toplum yapısındaki örgütlenme, iş bölümü ve davranış yapısını içinde barındıran nüfus birikim süreci olarak bilinmektedir. Bu çerçevede, herhangi bir inovasyon sürecine dahil olunmadan nüfus yoğunluğu bazındaki artış, gelişen teknoloji ile istenen refah seviyesine ulaşmak için gereken üretim-tüketim kaynaklarındaki artışla birlikte atık üretimi ve çevresel bozulmada artış yaratmakta ve orman alanlarında azalmaya neden olmaktadır. Elde edilen sonuçlar incelendiğinde, Türkiye'de atık yönetimine bağlı yükümlülüklerin tam olarak yerine getirilmemesi ve atıkların kısmen yeniden kullanılarak atık miktarının azaltılması yeterli düzeyde bir sürdürülebilirlik sağlayamadığı söylenebilmektedir. Çevre kirliliğinin azaltılması ve çevresel bozulmanın kendi kendini yenileyememe sınırlarına gelmesinin engellenmesi için ekonomik büyüme, sosyal gelişme ve çevre korumasını içinde barındıran sürdürülebilir kalkınma ile nitelikli politika tasarımlarının yapılması ve gelir gruplarına özgü aktif politikaların uygulanması gerekmektedir. Ek olarak, endüstriyel metabolizma ve ekoloji kapsamında, tüketim sonucunda çevresel bozulmaya neden olan atıklar etkili ayrıştırılarak, geri dönüşüm, döngüsel akış içine girerek diğer endüstrilerde kaynak ihtiyacını karşılayan hammadde olarak işlem görebilmektedir. Bunun sonucunda ise hem doğal kaynak kullanımının sınırlandırılması hem de atık depolama alan ihtiyacının azalmasıyla değer yaratma süreci oluşmaktadır.

Sağlıkta dönüşüm programıyla farklı gelir gruplarının sağlık ihtiyaçlarının ortak bütçeden karşılanması ve kamu-özel hastaneler arasında rekabet ortamının oluşması sağlanarak hizmet iyileşmesi hedeflenmektedir. Sağlığa yapılan yatırımlar beşerî sermayeyi, fiziksel yatırımları ve verimliliği arttırarak kalkınmayı sağlarken; sağlık sektörünün zayıf olması sermayenin verim- 
liğini azaltmaktadır. Yönetsel sosyoekonomik sistem olan iller bazında gelişmişlik seviyesi ve beşerî sermaye yapısı incelendiğinde, uygulamaya konan sağlık politikaları ve planlamaları kapsamında, kentlerde sağlık tesislerinin niteliklerinde değişim gözlemlenmektedir. İllerin nitelikli yatak sayısının toplam yatak sayısına oranı, ilin sağlık sektöründeki gelişmişlik düzeyini göstermektedir. Türkiye'de nitelikli yatak sayısındaki artışın kentleşme üzerine istatistiksel olarak anlamlı ve pozitif yönde etkisi belirlenmektedir. Niceliksel olarak fazla olan hastane yatak sayısının niteliksel olarak da giderek arttı̆̆ söylenebilmektedir.

Teknolojik gelişmelerle ürüne/bilgiye ulaşımın kolaylaşması, ucuzlaşması ve yönetimin hizmet-dağılım etkinliklerini sağlaması kentleşmenin hızlanmasında önemli rol oynarken; teknolojik altyapının sağlanmasıyla bilgi toplumuna geçişin hızlanması ve yeniliklerin benimsenmesi sermaye yapısını bilgi üstünden şekillendirdiğinden toplum yapısında ve davranışında farklılıklara neden olabilmektedir. Türkiye'de fiber optik uzunluğundaki artısın kentleşme üzerine istatistiksel olarak anlamlı ve pozitif yönde etkisi belirlenmektedir. Teknolojik alt yapının olmaması veya iyileştirilmemesi sonucu bilgiyi saklama, paylaşma ve ulaşma ihtiyaçları karşılanmadığında beşerî sermaye yoksulluğu ortaya çıkmaktadır. Endüstriyel gelişme ve ölçeğin genişlemesi ekonomik büyümeye yol açtığından bir kentin endüstriyel karlılığı ne kadar yüksek olursa, kentin verimliliği de o kadar yüksek olmaktadır. Endüstriyel ölçeğin genişlemesini ve finansal mallar ile emek üretim mallarının tüketimindeki artışlara bağlı olarak, kaynakların tam kullanımı ve üretim verimliliği endüstriyel kalkınmadaki ilerlemeyi tanımlamakta ve sanayi ölçeği ile kentsel rekabeti olumlu yönde etkilemektedir. Gelişmiş olan ülkelerde kentleşme ve kentsel inovasyon doğrudan patent ve faydalı model sayısına bağlı olmakla birlikte; Türkiye'de patent ve faydalı model başvuru sayılarının kentleşme üzerine istatistiksel olarak anlamlı ve negatif yönde etkisi belirlenmektedir. Ülkeler karşılaştırmalı üstünlükler teorisi kapsamında üstün oldukları ürünün üretiminde uzmanlaşarak üretimde pahaliya neden olan ürünü ithal etmeyi tercih etmektedirler. Gelişmekte olan ülkelerde, sürdürülebilir büyüme ve verimlilik için yeterli kaynak bulunmamasının yanı sıra birçok maliyet kaleminin bulunması, teknoloji gibi unsurların satın alınmasını gerektirmektedir. Her ne kadar teknoloji geliştirme ile ilgili devlet teşvikleri ve hükümet politikaları olsa da teknoloji üretmede hammadde konusunda dişa bağımlı olunması Türkiye'nin teknoloji üreten değil teknoloji ithal eden bir ülke olmasına neden olmaktadır. Bu durumda kentsel inovasyon 
stratejilerinde kullanılan tüm teknolojiler ithal olmakta ve yerel yönetim birimleri kullandıkları basit teknolojileri bile satın alabilmektedir. Kullanılan teknolojiler satın alınmayıp üretilmek istenirse çok yüksek maliyetlerle karşılaşılmaktadır. Bununla beraber, faydalı model ürünlerinin yeni olmayıp birçoğunun başkaları tarafından üretildiği ve/veya tasarım tescillerinin piyasada olan ürünleri kapsadığı düşünüldüğünden niteliksel olarak yeterlilikleri sorgulanmaktadır. Türkiye'de fikir/ürün geliştirmeye yönelik düşünce sisteminin yaygınlaştırılamaması, kavramsal bilgi eksikliği, hukuki boşluklar, yeterli kaynak ayrımının sağlanmaması AR-GE kültürünün oluşumunu engellemektedir. Kentler, inovasyon sürecinde AR-GE faaliyet üretimi yerine sadece kullanımın da tercih edebilmektedirler. Kentsel inovasyon için kullanılan bilgi teknolojilerinin yüzde 85'i zayıf planlama, yetersiz iş gücü, üst yönetim desteğini alamama, liderlik vasfının olmaması, uzmanların azlığı/yokluğu, organizasyonel hedefler ile proje hedefleri arasında uyum sağlayamama, çok fazla teknoloji odaklılık ve/veya kamu sektörü kentsel inovasyon projelerinin kendisinin bir oksimoron olmasından dolayı başarısızlıkla sonuçlanmaktadır. Devlet kurumları ve risk almayan yapılandırılmış bürokrasiler öğrenme, deney yapma, doğaçlama gibi durumlara kolayca adapte olamadıklarından kamu sektörü projeleri inovasyon için çok açık ve esnek değildir. Bu kapsamda, iller bazında patent ve faydalı model sayısındaki artışın sürdürülebilir büyüme, verimlilik ve dolayısıyla kentsel inovasyona neden olmadığı ve kentleşmenin bu kapsam dişında sadece kırsal kesimdeki kentleşme türü olan kente göç olarak değerlendirilebileceği sonucuna varılmaktadir. 


\section{Extended Abstract}

\section{Spatial Effect of Urban-Innovation on Urbanization}

\author{
M. Kenan Terzioğlu \\ ORCID: 0000-0002-6053-830X \\ Senem Demirkıran \\ ORCID: 0000-0001-9835-4963
}

\author{
Mehmet Ali Yücel \\ ORCID: 0000-0002-5474-3307 \\ Doğaç Acaroğlu \\ ORCID: 0000-0002-0055-1449
}

Cities that adapt to the changes in social structure caused by evolving technology and globalization emerge as open systems that interact with the process of innovation, where new ideas emerge and knowledge is spread. Urban innovation emerges as a way to solve the complexities and challenges arising from rapid urbanization; it helps ensure sustainable urban development in developing countries. Significant changes are observed in settlement stages both in the internal structures of cities and in the spatial differentiation of population, capital, and activity distribution. While there are successful examples of urban innovation in developed countries, developing countries acquire the technology for urban innovation from developed countries in an effort to create smart cities. Structural changes in societies alter perceptions of housing. As inequalities and irregularities in urban structure affect the country, housing policies are important in urbanization policies. It is necessary to examine the impact of the increase in residential property ownership on urbanization, which is seen as social security for middle- and low-income groups and as a means for wealth accumulation and investment for the high-income group in Turkey. Rising in parallel with industrialization and sustainable development, which are among the conditions of social and economic development, urbanization is known as the process of accumulation of population; this in itself encompasses the organization of the structure of society, division of labor, and behavioral framework. The increase in population density without any involvement in the process of innovation and the increase in the production-consumption resources required to achieve the desired level of prosperity with developing technology, 
as well as the effects on forestation, waste production, and environmental degradation should also be examined. The health transformation program in Turkey aims to improve services by providing health services to different income groups from a public budget and by creating a competitive environment among public-private hospitals. While investments in healthcare lead to development through increased human capital, physical investments, and productivity, a poor healthcare sector reduces the efficiency of capital. By examining the level of development and human capital structure on the basis of provinces (i.e., the administrative socioeconomic system), it is necessary to observe within the scope of health policies and planning the changes in the attributes of health facilities in cities. As access to products and information become increasingly easier and cheaper, administrations providing better services and distribution operations by using technological innovation play an important role in accelerating urbanization. The acceleration of transition to an information society and the adoption of innovations can cause differences in the structure of society and behaviors because it uses information to shape the structure of capital. In the scope of the theory of comparative advantages, countries prefer to import products that are expensive to produce and to specialize in producing goods and services in which they have an advantage. Developing countries are required to purchase technology because they do not have enough resources for sustainable growth and efficiency and are burdened with numerous items of expenditure. As cities may prefer to utilize rather than conduct research and development activities in the process of innovation, the evaluation of technological infrastructure and research-development activities is necessary. In this context, the plan is to discover the effects of the process of innovation on urbanization using urban innovation indicators such as the number of specialized beds in hospitals per province as indicators of investments in the health sector, the average amount of waste per capita and forest area per province as indicators of environmental activity, length of fiber optic cable as an indicator of technological infrastructure expenditure, number of patent applications and utility models per province as an indicator of research and development activities, and the number of residential real estate sales per province as an indicator of long-term savings made by individuals. This study was aimed at discovering, taking into account the year 2018, the effects of the variables of environmental activity indicators such as that of infrastructure, research and development activity, healthcare investment, and individual investment-savings on urbanization in Turkey, which is a developing country with development-focused policies, as well as contributing to the literature in the field by researching spatial 
impacts on urbanization on the assumption of the possibility of interaction between provinces - in other words, to understand if urbanization has a spatial distribution. Spatial econometry demonstrates the structure (interaction) of the relationship between locations and reveals spatial effects. Because the variables discussed within the scope of the article tend to create externality by creating the effect of propagation, it is aimed to identify the spatial effect of urban innovation indicators on urbanization by using spatial models for creating weight matrices, investigating the presence of autocorrelation, and determining contradictions/clusters and visualization of distributions. Urban innovation indicators and the presence of a homogeneous structure in terms of urbanization are questioned on a provincial basis. In this context, it has been determined that there is a significant difference in the level of urbanization in Turkey; the provinces in the western and eastern regions of the country have different characteristics, and they are in a spatial interaction by displaying a heterogeneous structure within themselves. In addition, the variables considered as indicators of urban innovation can provide information regarding whether a sustainable economic structure or just a growth-oriented structure is predominant in Turkey. Taking into account indicators of human capital, the environment, and infrastructure, this study explored whether the increase in urbanization is because of urban innovation or arising from an economy solely based on industrialization and focused on growth, which as a part of rural abandonment and does not involve eco-innovation and eco-productivity. In this context, it has been concluded that due to the increase in the number of patents and utility models, in average waste amounts, and in forested areas per province have a negative impact on urbanization, urban innovation has not been completely implemented with respect to sustainable growth and productivity, and only a growth-focused process is conducted; thus, urbanization can only be interpreted as urban migration, which is a kind of rural urbanization.

\section{Kaynakça/References}

Akubue,A. I. (2002) .Technology transfer: A third world perspective. Journal of Technology Studies, 28(1), 14-21.

Anselin,L. (1988) .Model validation in spatial econometrics: a review and evaluation of alternative approaches. International Regional Science Review, 11(3), 279-316.

Anselin,L. (1990) .Some robust approaches to testing and estimation in spatial econometrics. Regional Science and Urban Economics, 20(2), 141-163.

Anselin,L. (1995) .Local indicators of spatial association-LISA. Geographical analysis, 27(2), 93-115. 
Anselin,L. ve Bera,A.K. (1998). Introduction to spatial econometrics. Handbook of applied economic statistics, 237.

Anselin,L., Le Gallo,J. ve Jayet,H. (2008) .Spatial panel econometrics. Springer, Berlin, Heidelberg.

Bera,A.K. ve Yoon, M.J. (1993). Specification testing with locally misspecified alternatives. Econometric theory, 9(4), 649-658.

Berdegue, J. ve Escobar, G. (2002). Rural diversity, agricultural innovation policies and poverty reduction. Agricultural Research and Extension Network.

Birleşmiş Milletler, (UN). (2013). Science, technology and innovation for sustainable cities and peri-urban communities, Report of the Secretary-General, Economic and Social Council, Commission on Science and Technology for Development, 2013

Capello, R. (2001). Urban innovation and collective learning: theory and evidence from five metropolitan cities in Europe. Knowledge, complexity and innovation systems. Springer, Berlin, Heidelberg.

Darmofal, D. (2006). Spatial econometrics and political science. In Annual Meeting of Southern Political Science Association, Atlanta, GA, 5-7.

Demir,K.A., Döven G. ve Sezen,B. (2019). Industry 5.0 and Human-Robot Co-working. Procedia Computer Science, 158, 688-695.

Demiral,B. (2005). Sürdürülebilir kentler ve bölge. Planlamada Yeni Politika ve Stratejiler: Riskler ve Fırsatlar 8 Kasım Dünya Şehircilik Günü 29. Kolokyumu, 252-260.

Demiral,N., Evin,H. ve Demiral,B. (2007). Yoksulluğun küreselleşmesi ve küresel yoksulluk, IV. Uluslararası Sivil Toplum Kuruluşları Kongresi, 19-21.

Dente,B., Bobbio, L. ve Spada, A. (2005). Government or governance of urban innovation? A tale of two cities. DisP-The Planning review, 41(162), 41-52.

Elhorst, J. P. (2011). Spatial panel models. York, UK: The University of York.

Enhancinh Productivity in UK Core Cities. (2020). Connecting Local and Regional Growth, OECD Urban Policy Reviews.

Fischer,M.M. ve Wang,J. (2011). Spatial data analysis: models, methods and techniques. Springer Science \& Business Media.

Gumprecht, D. (2007). Spatial methods in econometrics (Doctoral dissertation, WU Vienna University of Economics and Business).

Gutzmer, A. (2016). Urban innovation networks. Springer Books.

Goi,C.L. (2017). The impact of technological innovation on building a sustainable city. International Journal of Quality Innovation, 3(6), 9-13.

Komninos,N. ve Sefertzi,E.(2009).Intelligent cities: R\&D offshoring, Web 2.0 product development and globalization of innovation systems. Second Knowledge Cities Summit, 2009.

Kremic,T. (2003). Technology transfer: a contextual approach. The Journal of Technology Transfer, 28(2), 149-158.

Krugman P. (1979). A model of innovation, technology transfer, and the world distribution of income. Journal of political economy, 87(2), 253-266. 
LeSage, J.P. (1999). The theory and practice of spatial econometrics. University of Toledo. Toledo, Ohio, 28.

Macomber, J.D. (2013). Building sustainable cities. Harv Bus Rev, 91(7/8), 40-50.

Mitchell, W.J. (2007). Intelligent cities. UOC papers, 5, 3-8.

Mol, A. P. (2009). Urban environmental governance innovations in China. Current Opinion in Environmental Sustainability, 1(1), 96-100.

Nahavandi, S. (2019). Industry 5.0-A Human-Centric Solution. Sustainability, 11(16), 4371.

Nam,T. ve Pardo, T.A. (2011). Smart city as urban innovation: Focusing on management, policy, and context. In Proceedings of the 5th international conference on theory and practice of electronic governance, 185-194.

OECD. (2020). OECD Urban Policy Reviews. OECD Publishing.

OECD. (2020). Enhancing productivity in UK Core Cities connecting local and regional growth. OECD Publishing.

Oosterlynck, S., Kazepov, Y., Novy, A., Cools, P., Barberis, E., Wukovitsch, F. ve Leubolt, B. (2013). The butterfly and the elephant: local social innovation, the welfare state and new poverty dynamics. Improve Paper.

Ritchie, H. ve Roser, M. (2019). Urbanization. Our World In Data

Schiederig, T., Tietze, F. ve Herstatt, C. (2012). Green innovation in technology and innovation management-an exploratory literature review. RED Management, 42(2), 180-192.

Simmie, J. (2003). Innovation and urban regions as national and international nodes for the transfer and sharing of knowledge. Regional studies, 37(6-7), 607-620.

Skobelev, P. O. ve Borovik, S. Y. (2017). On the way from Industry 4.0 to Industry 5.0: from digital manufacturing to digital society. Industry 4.0, 2(6), 307-311.

Soplop J., Wright, J., Kammer, K. ve Rivera, R. (2009). Manufacturing execution systems for sustainability: Extending the scope of MES to achieve energy efficiency and sustainability goals

Suthersanen, U. (2006). Utility models and innovation in developing countries (No. 13), International Centre for Trade and Sustainable Development (ICTSD).

Tatlı, S. (2016). Mekansal ekonometrik modeller ve türkiye'de iç göçün belirleyicilerinin analizi. Yülsek Lisans Tezi , İstanbul Üniversitesi Sosyal Bilimler Enstitüsü Ekonometri Anabilim Dalı.

Tekeli, İ. (2016). Yerleşmeler için temsil sorunları ve strateji önerileri. İdealkent Yayınları: Ankara.

Tekeli, İ. (2019). Ülkesel/Milli fiziki plan üzerinde dördüncü kez konuşurken, Sketch Journal of City and Regional Planing, 1, 1-14

While, A., Jonas, A.E. ve Gibbs, D. (2004). The environment and the entrepreneurial city: searching for the urban 'sustainability fix' in Manchester and Leeds. International Journal of Urban and Regional Research, 28(3), 549-569.

Viton, P.A. (2010). Notes on spatial econometric models. City and regional planning, $870(3), 1-23$. 